\title{
Ecosystem Services from Small Forest Patches in Agricultural Landscapes
}

\author{
Guillaume Decocq $^{1} \cdot$ Emilie Andrieu $^{2} \cdot$ Jörg Brunet $^{3}$ - Olivier Chabrerie ${ }^{1}$. \\ Pieter De Frenne $^{4}$ - Pallieter De Smedt ${ }^{4}$ - Marc Deconchat ${ }^{2} \cdot$ Martin Diekmann $^{5}$. \\ Steffen Ehrmann ${ }^{6} \cdot$ Brice Giffard $^{2} \cdot$ Elena Gorriz Mifsud $^{7} \cdot$ Karin Hansen $^{8}$. \\ Martin Hermy ${ }^{9}$ - Annette Kolb ${ }^{5}$. Jonathan Lenoir ${ }^{1}$ - Jaan Liira ${ }^{10}$ - Filip Moldan ${ }^{11}$. \\ Irina Prokofieva ${ }^{7}$ - Lars Rosenqvist $^{8}$ - Elsa Varela ${ }^{7,12}$ - Alicia Valdés ${ }^{1} \cdot$ Kris Verheyen $^{4}$. \\ Monika Wulf ${ }^{13,14}$
}

Published online: 29 January 2016

(C) Springer International Publishing AG 2016

\begin{abstract}
In Europe, like in many temperate lowlands worldwide, forest has a long history of fragmentation and land use change. In many places, forest landscapes consist of patches of different quality, age, size and isolation, embedded in a more or less intensively managed agricultural matrix. As potential biodiversity islets, small forest patches (SFP) may deliver several crucial ecosystem services to human society, but they receive little attention compared to large, relatively intact forest patches. Beyond their role as a biodiversity reservoir, SFP provide important in situ services such as timber and wild food (game, edible plants and mushrooms) production. At the landscape scale, SFP may enhance the crop production via
\end{abstract}

This article is part of the Topical Collection on Ecological Function

Guillaume Decocq

guillaume.decocq@u-picardie.fr

1 UR Ecologie et Dynamique des Systèmes Anthropisés (EDYSAN, FRE 3498 CNRS), Jules Verne University of Picardie, 1 rue des Louvels, F-80037 Amiens Cedex 1, France

2 UMR 1201 Dynafor, Inra, Chemin de Borde Rouge, CS 52627 , F-31326 Castanet Tolosan, France

3 Southern Swedish Forest Research Centre, Swedish University of Agricultural Sciences, Box 49, SE-230 53 Alnarp, Sweden

4 Forest \& Nature Lab, Ghent University, Geraardsbergsesteenweg 267, BE-9090 Melle-Gontrode, Belgium

5 Institute of Ecology, FB02, University of Bremen, Leobener Str., D-28359 Bremen, Germany

6 Faculty of Biology, Department of Geobotany, University of Freiburg, Schänzlestr. 1, D-79104 Freiburg, Germany physical (obstacle against wind and floods) and biological (sources of pollinators and natural enemies) regulation, but may, on the other hand, also be involved in the spread of infectious diseases. Depending on their geographic location, SFP can also greatly influence the water cycle and contribute to supply high-quality water to agriculture and people. Globally, SFP are important carbon sinks and are involved in nutrient cycles, thus play a role in climate change mitigation. Cultural services are more related to landscape values than to SFP per se, but the latter may contribute to the construction of community identity. We conclude that SFP, as local biodiversity hotspots in degraded landscapes, have the

7 Forest Sciences Center of Catalonia (CTFC), St. Pau Historical Site, St. Leopold Pavilion, c/St. Antoni Maria Claret 167, 08025 Barcelona, Spain

8 IVL Swedish Environmental Research Institute, Box 210 60, SE-100 31 Stockholm, Sweden

9 Division of Forest, Nature and Landscape, University of Leuven, Celestijnenlaan 200E, B-3001 Leuven, Belgium

10 Institute of Ecology and Earth Sciences, University of Tartu, Lai 40, EE-51005 Tartu, Estonia

11 IVL Swedish Environmental Research Institute, Box 530 21, SE-400 14 Gothenburg, Sweden

12 Center for Agro-Food Economy and Development, CREDA-UPC-IRTA, Edifici ESAB. Parc Mediterrani de la Tecnologia C/Esteve Terrades 8, Castelldefels, E-08860 Barcelona, Spain

13 ZALF Institute of Land Use Systems, Eberswalder Straße 84, D-15374 Müncheberg, Germany

14 Institute of Biochemistry and Biology, University of Potsdam, Maulbeerallee 2, D-14469 Potsdam, Germany 
potential to deliver a wide range of ecosystem services and may even be crucial for the ecological intensification of agroecosystems. There is thus an urgent need to increase our knowledge about the relationships between biodiversity and ecosystem services delivered by these SFP in agricultural landscapes.

Keywords Biodiversity · Cultural services · Lowlands · Provisioning services $\cdot$ Regulating services $\cdot$ Supporting services

\section{Introduction}

Habitat fragmentation is widely acknowledged as a major threat to biodiversity worldwide [1-3], but see [4]. It encompasses at least four interacting processes: (i) pure habitat loss, which usually directly destroys sessile organisms (e.g. plants) and constrains mobile organisms (e.g. birds and mammals) that retreat into remnant patches of habitat; (ii) reduction of fragment size, which reduces species richness and population sizes, increasing the risk of local extinction [5]; (iii) increase in edge:interior ratio, which can promote the colonisation of habitat generalists and species from neighbouring habitats to the detriment of habitat specialists that have retreated to remnants [6]; and (iv) increase in spatial isolation of remnant habitat patches, which reduces the movements of individuals between populations [7] and disrupts metapopulation and metacommunity functioning $[8,9]$. In Europe, forest has a long history of fragmentation and land use/cover change [10-12]. The clearance of forests for agriculture and their recovery on abandoned lands resulted in patchy forest cover with patches of different quality, age, size and isolation embedded in a more or less intensively managed agricultural matrix. Ecologically, these forest patches often exhibit homogenized stand structure, either because they are intensively managed or originate from plantations or afforestation of former farmlands [13-15], or management can be neglected [16].

The increasing demand for food and the promotion of bioenergy crops in the context of a bio-based energy transition have led to an increasing demand for new agricultural areas worldwide and increased crop production to the detriment of semi-natural habitats, including forests [17]. Therefore, landscape change in the forms of clearance of existing forest patches and afforestation of abandoned lands are still ongoing processes in European lowlands [18•]. In general and at the same time, forests are of major importance to human society, delivering several crucial ecosystem services [19••], but also some disservices (e.g. diseases [20]). There is growing evidence that biodiversity is vital to ecosystem functioning $[21-23,24 \cdot, 25,26]$. By decreasing biodiversity, fragmentation may thus impact ecosystem processes such as nutrient cycling and energy flows and ultimately affect flows of ecosystem service $[27,28 \bullet \bullet$. Ecosystem services (ES) are often categorized as provisioning, regulating, cultural and supporting services [29]. Costanza [30] proposed an alternative classification based on the spatial characteristics of ES, using five categories: in situ, local-proximal, directional flow related, global and user movement related.

Compared to large forest ecosystems, e.g. [19••, 31], little is known about the role of biodiversity of small forest patches (SFP, from less than 1 to $50 \mathrm{ha}$; [32]) in delivering ES to society $[33 \cdot, 34 \cdot \bullet]$ in agricultural landscapes, which cover $40 \%$ of the Earth's surface [35]. The research effort has indeed mostly focused on how forest fragmentation actually alters the delivering of ES. Furthermore, these SFP are potentially threatened by urbanisation, expanding croplands and agricultural intensification despite their potential to maintain biodiversity and contribute to the "ecological intensification" of agro-ecosystems [36] and human well-being. Thus, there is an urgent need to increase our understanding of the relationship between biodiversity and ES delivered by SFP embedded in an agricultural landscape matrix (Fig. 1). We here review the literature on the topic, with a special focus on temperate European landscapes and make profit from still unpublished results of the smallFOREST BiodivERsA project into which all co-authors of this paper were involved. Following Costanza's classification [30], we successively review in situ ES (i.e. that are delivered locally, within the ecosystem), localproximal ES (i.e. that depends on the spatial proximity of the focal ecosystem), directional flow-related ES (i.e. from the ecosystem to the point of use), global ES (i.e. independent from ecosystem location) and user movement-related ES (i.e. involving a movement of people towards the ecosystem) (Table 1).

\section{In Situ Services}

\section{Biodiversity}

Most contemporary SFP are young, in an early secondarysuccessional stage, homogeneous in their structure, and, as a consequence, host only a few forest-specialist species [37-40]. The sensitivity of biodiversity components to remnant habitat size and habitat structural quality varies significantly [41-43]. Sessile and less mobile organisms are more threatened by habitat degradation $[40,44-46]$ in comparison to species with good dispersal or mobility $[47,48 \cdot]$. The effect of fragmentation on species richness and community composition in forests is mediated by four main groups of variables: (1) forest patch quality in terms of soil variables, notably $\mathrm{pH}$, nutrient availability and light [11, 49]; (2) patch heterogeneity, i.e. the variability of environmental drivers and stand diversity $[50,51]$; (3) habitat configuration in terms of forest patch size and isolation $[49,52]$; and (4) the history of the patch, 

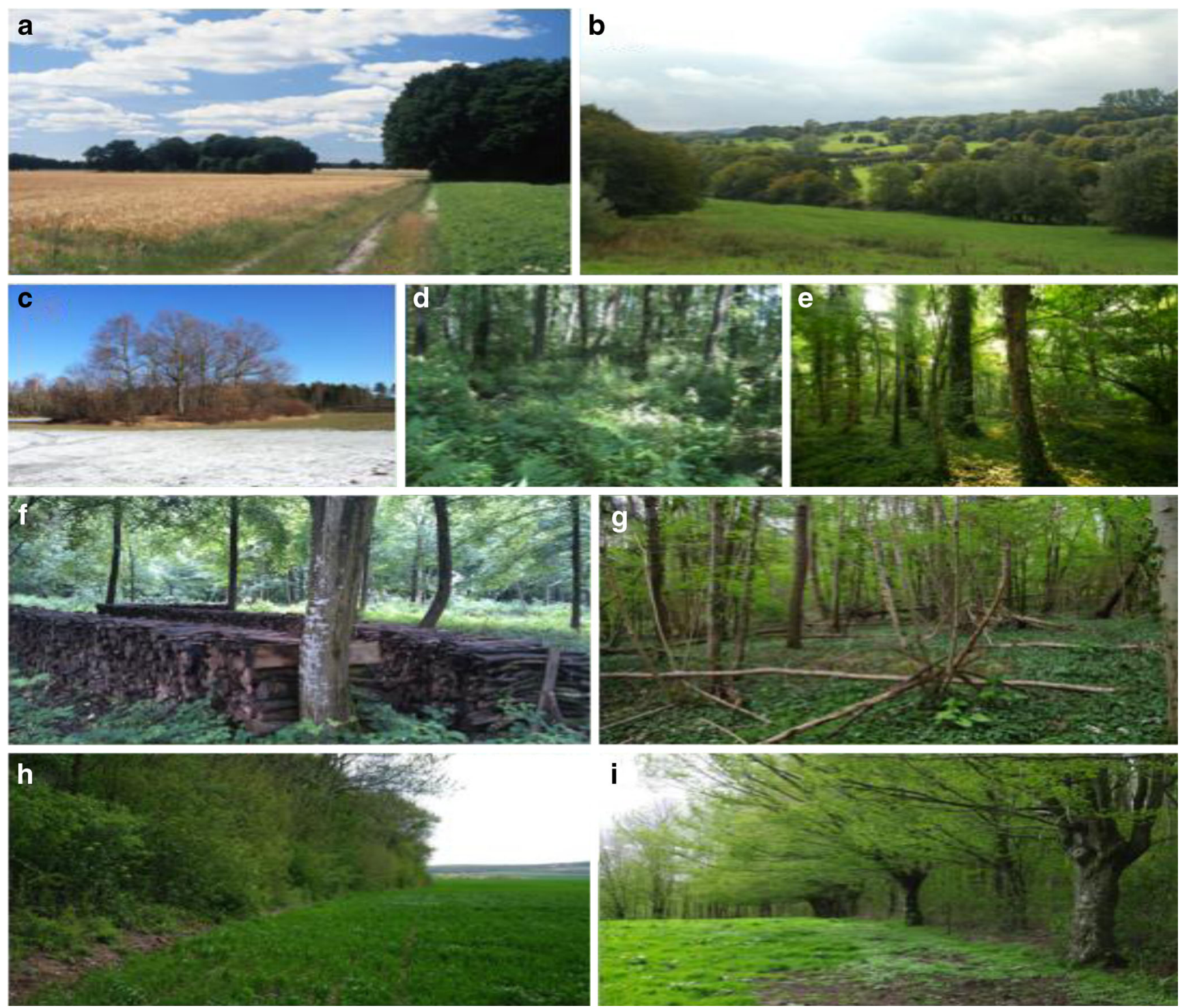

Fig. 1 Various aspects of small forest patches in European agricultural landscapes. Small deciduous forests look like isolated patches within intensively cultivated open fields (a) or more or less connected by hedgerows within grasslands (b); even sometimes as small islets in a coniferous-dominated landscape (c). These small forest patches are often hotspots of biodiversity within agricultural landscapes, with a species-rich herb layer (d) and a mixture of deciduous tree species (e). These patches are sometimes managed for wood production (f) but are often unmanaged (g). They potentially deliver a wide range of ecosystem services to neighbouring crop lands (h) and pastures (i), such as pest

biocontrol and shelter for grazing animals, respectively. a Open fields in North-West Germany (A. Kolb); b bocage of Thiérache (A. Jamoneau), North France; c agricultural landscape in Central Sweden (G. Decocq); d understory in an alder stand in North-East Germany (M. Wulf); e understory of Flanders in Belgium (E. Brosens); $\mathbf{f}$ fuel wood harvest in North France (J. Lenoir); g unmanaged woodlot in North France (G. Decocq); $\mathbf{h}$ forest edge in an open field landscape of North France (G. Decocq); $\mathbf{i}$ forest edge in an open field landscape of North France (G. Decocq)

especially whether it has been continuously forested for centuries (ancient forest) or afforested on agricultural land (recent forest) $[52,53]$. Generally, the number of species in SFP increases with increasing patch area, decreasing isolation, increasing heterogeneity and temporal continuity, while the effects of patch quality are more complex and often species specific. Edge effects may have negative impacts on forest specialists due to altered microclimate (e.g. [54, 55] for fungus species diversity). Forest management and the creation of novel forest habitats such as parks do not always have a

negative effect on forest biodiversity, as the optimization of stand structure can result in SFP that support a high diversity of vascular plants [56, 57], insects [58, 59] and bats [60, 61]. The positive effect of management on biodiversity, however, is generally driven by the increase of habitat generalists or open habitat species [43, 62]. As a result, the positive species-area relationship underlying the patch size effect in some cases has been weak or absent (e.g. [63] for plants; [64] for arbuscular mycorrhizal fungi), meaning that even SFP may comprise a high number of species [65]. Moreover, 
Table 1 Ecosystem services delivered by small forest patches embedded in agricultural landscapes that are assessed in this review (right part), grouped in five classes according to their spatial characteristics (left part), after [30]

\begin{tabular}{|c|c|}
\hline In situ services & - Biodiversity \\
\hline \multirow[t]{3}{*}{$=$ services delivered within the forest patch } & - Wood production \\
\hline & - Wild food production \\
\hline & - Biological invasion risk (disservice) \\
\hline Local-proximal services & - Disturbance regulation \\
\hline \multirow[t]{4}{*}{$=$ services depending on the spatial proximity of the forest patch } & - Habitat \& refuge \\
\hline & - Biological pest control \\
\hline & - Pollination \\
\hline & - Infectious diseases (disservice) \\
\hline Directional flow-related services & - Water regulation \\
\hline \multirow[t]{2}{*}{$=$ services extending from the forest patch to the point of use } & - Water supply \\
\hline & - Erosion control \\
\hline Global services & - Carbon storage \& climate regulation \\
\hline$=$ services independent from the forest patch location & \\
\hline User movement-related services & - Recreational activities \\
\hline \multirow[t]{2}{*}{$=$ services involving a movement of people towards the forest patches } & - Aesthetics \\
\hline & - Construction of local identity \\
\hline
\end{tabular}

irrespective of the variation in the environment, a dense network of SFP can contribute to counteracting the disruption of the meta-population functioning of the landscape with respect to new colonization events [9], depending on the species dispersal ability [43, 66]. On the other hand, many long-lived organisms, such as some vascular plant species, may persist over many decades even under non-favourable conditions. This "extinction debt" of species in SFP offers an opportunity to halt biodiversity loss by taking conservation action in time $[67 \bullet]$.

\section{Wood Production}

SFP may be important for local timber and firewood production as a provisioning ES. In Western Europe, a heavily fragmented region with a mean forest cover of c. $26 \%$, $93 \%$ of all forests were available for wood supply [68]. In total, 172 million cubic metres of wood were harvested in this region in 2010. Nevertheless, the mean patch size of private forests, for instance, in Belgium, the UK and Germany is only 2, 13 and 10 ha, respectively [69]. Wood production in these forests is faced with management challenges like a high number of forest owners and a patchy occurrence of the wood resource, which - nevertheless - could partly be resolved by a specific local organization [70]. Close-to-nature management systems such as continuous cover, retention forestry or selective logging of single trees can often be a good option for wood production in SFP because they most likely sustain the continued delivery of other $\operatorname{ES}[71,72 \bullet$. Given that the demand for fuel wood is expected to continuously increase in the near future, the pressure on SFP to provide local inhabitants with wood in densely populated areas is expected to increase over the next few decades [73].

\section{Wild Food Production}

Wild food provision, of which the most iconic components are game hunting and mushroom picking, is hardly accounted for in any mapping of ES in Europe. A key aspect that regulates the availability of wild food (including hunting) is a heterogeneous landscape that is threatened by agricultural intensification $[30,74,75]$. SFP can provide a wide range of edible plant products (e.g. wild berries and nuts) and mushrooms, which are commonly used by local populations and/or marketed. A recent study revealed that 11 wild plant species were still used as food in Sweden but none as medicinal plants, whilst in the economically less developed rural areas of Ukraine, 26 and 60 species are used as food and herbal, respectively, suggesting that the consumption of wild food and medicine is influenced by the socioeconomic situation in a country [76]. In western Europe, a considerable number of forest plant species have been used in the past (22.2 and $13.6 \%$ for food and medicinal applications, respectively, out of a total species pool of 1024 species; smallFOREST project, unpublished data). Thus, gathering of wild food may be considered more of a cultural service in Europe and part of people's identity [77], with the potential for increasing demand in response to industrialization [78].

SFP can also act as a refuge for game animals (e.g. roe deer, wild boar, hare, rabbit and pheasant). Mammals such as hares and roe deer are generalist herbivores that move and forage freely across agricultural landscapes and can use SFP as a source of food and as shelter during periods of agricultural activity in neighbouring croplands [79, 80]. Their value as hunting reservoirs is often one of the main reasons that have prevented these SFP from being converted into agricultural land [81]. 


\section{Biological Invasion Risk}

Habitat loss and fragmentation are thought to promote the spread of invasive species. An increased risk of biological invasion can be seen as a disservice provided by SFP, and it may alter some of the beneficial ES and thus have huge costs to society [82]. In some countries, exotic tree species have been widely used for reforestation [83]. However, the assumption that SFP are more exposed to invasion mainly comes from percolation-based model simulations [84], and empirical evidence is still scarce. It has also been suggested that fragmentation may slow down invasion spread, at least for species that are not dispersal-limited [84], and therefore, SFP might also provide a beneficial ES in this sense. A negative relationship between patch size and exotic species richness has been repeatedly found [85-87], but other landscape factors (e.g. landscape composition and configuration, management intensity and proximity from seed sources) interact with patch invasibility. Although forest ecosystems are usually considered as resistant to biological invasion but see [88], fragmentation creates more edge, which offers a more suitable habitat than the forest interior for many exotic species that are not dispersal-limited and able to move through the landscape matrix [89]. It is likely that the (dis-)services associated to invasive species do not fundamentally differ between SFP and other forest ecosystems. For example, the Asian shrub Lonicera maackii, one of the most widespread invaders of US woods, has been shown to reduce the survival, growth and fecundity of native herbs and tree seedlings [90], hence, to negatively impact local biodiversity. A recent meta-analysis found that pollinator communities of bees and bumblebees were negatively impacted by the combined effect of fragmentation and biological invasions via the disruption of plantpollinator networks [91]. Another potential disservice is seed dispersal from small forests into adjacent cropland, but this has been shown to be limited, so that the forest edge cannot be regarded as an important source of weed infestation of crop fields [92].

\section{Local-Proximal Services}

\section{Disturbance Regulation}

Flooding, storm, wildfire or fast spread of pests and pathogens are disturbances that strongly affect human activities and have heavy financial consequences. Their frequency or their consequences are influenced by landscape characteristics, such as connectivity, that may contribute to the expansion of these disturbances. SFP may play a key role in this process and then provide a regulation ecosystem service. However, the low frequency of these events renders the study of how SFP may reduce their consequences challenging yet crucial since the occurrence and magnitude of such extreme events are predicted to increase with global warming [93]. Lindner et al. [93] reviewed the impacts of climate change on European forests with a special focus on the risks of greater disturbances, but without taking into account the spatial patterns of forest fragmentation. The analysis of past disturbance in European forests during the nineteenth and twentieth centuries did not address spatial patterns either [94] and as such little is known. SFP may, depending on their location in relation to farmland or housing, act as windbreaks and protect land against erosion, although there is a little research on this topic. It is generally admitted that several SFP scattered across agricultural and flat landscapes might be better than a one single large forest stand at reducing, breaking up and dissipating wind storms, but empirical results [95] do not always fit with this assumption, underlying the need for more detailed studies.

\section{Habitat/Refuge}

Of around 220 forest plants in northwest and central Europe (list in prep. by the FLEUR network, http://www.fleur.ugent. be/), two-thirds have been found in SFP along a latitudinal gradient from southern France to central Sweden [96••]. Small forest fragments are therefore important habitats for these habitat specialists. Moreover, it has been demonstrated that several habitat specialists can persist for many decades or even longer in SFP [67•, 97]. In general, SFP may serve as transitional habitats or stepping stones in a network of isolated forest habitats [59, 98•]. On the other hand, SFP can act as "lifeboat" habitats for species, particularly in landscapes with a high degree of fragmentation [99]. These fragments could ultimately act as climate refugia in the current context of climate change [100], as long as surface area is large enough to sustain a viable population and species are not bounded by matrix habitat and therefore unable to migrate due to climate change. However, obviously, microhabitat conditions within SFP offer short-term (e.g. minutes to days for wildlife inhabiting agricultural landscapes) protection from anthropogenic disturbances dominating in the surrounding matrix and thus act as "transit shelters" or "refuges" for biotas [101] (cf. disturbance regulation). Less obvious, the cooler and more stable conditions generated by forest canopy closure in SFP compared with the highly disturbed agricultural matrix (cf. vegetation-cover effect in [100]) may be partly responsible for the buffering effect on warming-induced community composition changes that have been reported in lowland forests [102, 103]. Coherently, it has been demonstrated through a manipulative experiment that light accelerates warminginduced changes in understory plant communities [104]. Given these recent findings, we argue that SFP have a strong potential to provide climatic refugia (cf. involving longer time scales than refuges), as a local-proximal ES. This is especially important in lowland agricultural landscapes [100], which are 
heavily disturbed by humans and where both habitat fragmentation and long distances between isotherms hinder species range shifts that are lagging behind climate change [105]. Noteworthy, the identification of climate refugia, such as SFP, within anthropogenic-disturbed lowland ecosystems and the assessment of their capacity for conservation planning under contemporary and future climate change has recently been highlighted as a daunting but timely endeavour [106].

\section{Biological Pest Control}

Biotic interactions associated with biodiversity can provide important local-proximal, regulating ES, particularly in terms of pest control in crop fields through natural enemy diversity from proximal non-crop habitats [107]. As a rough estimate, the value of pest control attributed to insect predators and parasitoids, which are primarily responsible for natural control in $33 \%$ of cultivated systems [108], has been estimated at $\$ 4.5$ billion per year [109].

SFP host a broad spectrum of natural pest-predators, from microbial pathogens to small mammals. Edges of forest fragments generate wider boundary areas, which operate as a source for biocontrol agents dispersing into adjacent matrix habitats just before pest outbreak [48•, 110-112]. Since SFP are often the last semi-natural habitat scattered across a matrix of agricultural landscapes $[62,113,114]$, they have the potential to offer environmental (reduced need of chemical pesticides) and economic benefits (reduced yield loss free of charge) to crop production [61, 115-119]. Although it is likely that smaller forest fragments provide fewer natural enemies than larger fragments, both in terms of richness and abundance, several SFP might be more efficient in providing a sufficient pressure of natural enemies on crop pests across an entire agricultural landscape than just a single large forest $[120,121]$, simply by providing more edge habitat. Mitchell et al. [34*0] found that insect herbivory regulation in soybean fields in Canada was maximized adjacent to forest fragments and decreased with distance from the forest fragment edge. Thompson and Hoffmann [122] showed that species of parasitoids and predators strongly aggregate close to SFP. Shackelford et al. [123] found a positive effect of the compositional complexity of agro-ecosystems (proximity to, diversity of or proportion of natural or non-crop habitats) on the abundance and richness of natural enemies, although this trend was mainly driven by spiders. Spiders are very mobile and generalist predators and have therefore a large potential in contributing to the natural pest control [124]. This confirmed former findings from Bianchi et al. [125] who showed that natural enemy populations were greater and pest pressure lower in heterogeneous landscapes containing a good mixture of crop fields and non-crop habitats (including SFP).

\section{Pollination}

Almost $90 \%$ of the world's Angiosperm plant species and about $75 \%$ of the most important global food crops depend, at least partly, on animal pollination [126, 127]. Pollinators thereby play a critical role in the maintenance of biodiversity and provide an essential intermediate ES to society. Habitat loss and fragmentation may influence pollination processes by affecting plant densities, pollinator densities and pollinator behaviour, all of which in turn may affect plant pollination success [91, 128-131]. Effects are often negative, for example, plants in fragmented populations may receive fewer flower visits, smaller pollen loads or pollen of poorer quality, thereby suffering pollen limitation and reductions in reproductive success [132-135], which may lower population viability and increase local population extinction risk.

However, SFP within agricultural landscapes are also habitats for insect species that provide pollination services in adjacent fields. The compositional complexity of agroecosystems has been shown to increase the abundance and species richness of crop pollinators, an effect which was even greater than the positive effect on natural enemies [123]. This further highlights the importance of non-crop habitats such as SFP in delivering local-proximal ES [136]. Indeed, crop pollination declines with the distance from natural or semi-natural habitats, with patterns being stronger in tropical than in temperate regions [137]. Moreover, Garibaldi et al. [138] found that temporal and spatial stability of pollination services also decrease with isolation from natural areas such as forest.

\section{Infectious Diseases}

SFP might also have a negative impact on human society through the provision of what has been called ecological disservices [139]. Among the most important disservices is the prevalence of ectoparasites like ticks (mainly Ixodes ricinus) that can transmit a variety of viruses, bacteria or parasites and thereby play an important role in providing infectious diseases to a wide range of animal hosts, including humans [140]. Lyme Borreliosis, which has Borrelia burgdorferi sensu lato as causative agent, is the most common infectious disease transmitted by ticks and seems most prevalent in central European countries [141]. Other tick-borne diseases include tick-borne encephalitis with ever increasing case numbers all over Europe (see [142] for a comprehensive study on all known tick-borne diseases occurring in Central Europe). In North America, landscape fragmentation seems to play a crucial role in explaining patterns of tick abundance and Lyme Borreliosis prevalence mediated by ungulate and small mammal dynamics [143]. The influence of the landscape context is not yet completely understood in Europe, but there are indications that landscape fragmentation is responsible for patterns of tick-borne encephalitis in European agricultural 
landscapes [144] and the prevalence of B. burgdorferi in forests and pastures [145]. This is presumably due to the greater amount of edges in fragmented landscapes where small vertebrates, ungulates and medium-sized mammals act as reservoir hosts. An important concept, the dilution effect, is based on higher diversity of potential tick-host species. Higher species richness results in fewer interactions between ticks and those host species known to be infective to ticks. A loss of biodiversity associated to landscape fragmentation might thus conversely increase the prevalence of pathogens in fragmented landscapes [146, 147].

Among emerging diseases, the African swine fever (ASF) might have an increasing socioeconomic impact (OIE-CIC Joint Meeting on ASF 2014). A close link between wild boar (Sus scrofa) ecology and the spread of ASF can be assumed, since both wild boar and domesticated pigs are vulnerable to ASF [148] and are suspected to infect each other [149]. Wild boar are known to show generalist life-history traits and while other medium to large mammals occur less frequently in fragmented landscapes, wild boar is less sensitive to fragmentation [150]. However, the response of infectious diseases less relevant to humans directly, and in particular diseases of domestic animals, to landscape fragmentation is still largely unknown.

\section{Directional Flow Related}

\section{Water Regulation}

Water quality is not only important for drinking supply but also to other hydrologic services, including recreation and freshwater biodiversity. Forests have important regulatory functions on the water cycle by fixing soils, modifying soil structure and producing litter. Due to their capacity for restricting or delaying water flow, forests regulate water flows in the ground, streams and rivers [151, 152], providing substantial economic values to human societies and activities downstream. As high-water-retention ecosystems, forests decrease both flood peaks and low flows [153], but the intensity of this effect varies with plant water use throughout the year, which depends upon interactions between seasonal growth patterns and local climate. Riparian forests promote the infiltration of surface water to groundwater, which reduces flood peaks while increasing base flow, thus increasing the predictability of water availability [154].

Since agriculture is widely acknowledged as a major source of water pollution, the water quality regulation ES provided by neighbouring SFP is of great interest. Trees are indeed able to capture, transform and store a wide range of chemicals, pathogens, excess nutrients, salts and sediments from surface and groundwater [155].

\section{Water Supply}

Water supply is crucial to a number of domestic, agricultural, commercial, industrial and electric power uses but also to the freshwater life. According to FAO, agriculture represents about $70 \%$ of the water use on Earth, of which $80 \%$ comes from rainfall stored in soils [156]. Water storage in soil depends upon plant cover, organic matter content and the biotic community [118]. Forests might increase infiltration while decreasing the total water volume due to transpiration [155]. The hydrologic effects of forests have been extensively debated, but in general the volume of surface and groundwater available from forested watersheds is lower than that from watersheds dominated with other land cover types [157].

In agricultural landscapes, water is a key factor to be managed to enhance the agricultural production. In rain-fed farming systems, maximizing soil infiltration of rainfall water and soil water holding capacity ensures good growth of crops. Land cover type and cycling through soils are hidden parts of the water cycle albeit crucial. It has been suggested that improving rainfall water retention by soils is a more suitable strategy than irrigation to increase crop productivity [156].

\section{Erosion Control}

The negative effects of soil erosion encompass water pollution and siltation, crop yield depression, organic matter loss and reduction in water storage capacity [158]. Forest ecosystems provide the most effective vegetation for preventing soil erosion, thereby contributing to soil protection $[159,160]$. Soil loss is generally more than an order of magnitude lower in forests than on arable land [160]. In managed forests, heavy forestry vehicles and mechanical operations associated with logging, as well as clearcutting practises cause important disturbances of the upper soil layers and ground vegetation, thus expose these areas to water run-off and soil erosion [161]. Since SFP are usually less intensively managed, the terrain they cover would be less prone to soil loss and run-off.

\section{Global Services}

The northern hemisphere is currently acting as a net terrestrial carbon (C) sink which has mainly been attributed to $\mathrm{C}$ sequestration in forests [162], of which a significant part is in boreal forests [163]. Current increases in the $\mathrm{C}$ stock of forest biomass have been estimated to range from 50 to $100 \mathrm{Tg} \mathrm{C}_{\text {year }}{ }^{-1}$ for Europe [164-167]. Most of the annual changes in the forest $\mathrm{C}$ stock are influenced by forest management, such as clearcutting and replanting, whereas smaller changes are due to natural disturbances $[69,167,168]$. In the wake of climate change, $\mathrm{C}$ sequestration and storage play an important role across all ecosystems [169]. The forest C stock is influenced 
by anthropogenic drivers such as climate change and nitrogen (N) deposition [170]. The magnitude of the $\mathrm{C}$ pools in forest soils depends on soil properties, particularly temperature and humidity [171] and dominant tree species [172, 173].

Forest fragmentation has the potential to affect $\mathrm{C}$ and nutrient cycling, through decreased area, increased isolation and greater exposure in forest edges [174, 175]. Fragmentation leads to drier and warmer edges with altered light availability and wind microclimate [176-178]. Advection and inflow of air cause forest edges to trap and concentrate wind-borne dry deposition of soil nutrients and pollutants from adjacent agricultural or industrial areas [179]. The large spatial variation in nutrient deposition fluxes in forest edges [180-184] generally points to the deposition of $\mathrm{N}$ being up to four times higher in the edge of the forest $(0-200 \mathrm{~m})$ than in the forest interior.

In temperate forests, the total $\mathrm{C}$ accumulated in biomass is generally limited by the availability of $\mathrm{N}$ since the cycling of $\mathrm{C}$ and $\mathrm{N}$ is closely linked [185]. Increased supplies of plant available $\mathrm{N}$ from deposition may stimulate tree growth and litter fall and result in increased biomass production and, consequently, additional C sequestration [186-188] as, for example, in a fragmented landscape with a higher forest edge density. This elevated forest productivity has been hypothesized to increase soil organic $\mathrm{C}$ stocks by increasing the $\mathrm{C}$ input to the soil and by reducing the decomposition of soil organic matter. There is evidence from respiration and litter decomposition studies that the effect of added $\mathrm{N}$ on the soil organic matter decomposition rate is negative [189-191] and that it might be responsible for up to a $10 \%$ increase in soil organic $\mathrm{C}$ stocks [162]. Remy et al. [unpublished data] recently showed that both $\mathrm{C}$ and $\mathrm{N}$ soil stocks were increased by approximately $30 \%$ at the forest edges compared to the forest interiors. Other unpublished data (Ginzburg, personal communication) found no edge effect on soil C stocks. In sum, the impact of forest fragmentation on $\mathrm{C}$ cycling and storage is still uncharted territory and should be the focus of future research.

\section{User Movement Related Services}

User-movement ES from SFP are represented by the recreational and aesthetic values they provide. The recreational potential of a forest is determined by access rights and customary traditions and, more specifically, by a series of factors such as population density, substitutive or complementary character of forests [192, 193], and proximity and accessibility to the forest patch [194-196]. Actual recreational values that people derive from forest stands can also depend on the activities they carry out in the forest [197]. Still some general trends have been ascertained such that the recreational preference for a forest increases with increasing tree size and stage of stand development [198, 199], including provision of view as an important factor [200].

In the case of SFP, the assessment of these values may be even more challenging since their contribution is highly determined by the agricultural matrices in which they are embedded. In general, more heterogeneous landscapes are appreciated [201-203] and SFP contribute substantially to heterogeneity in the agricultural landscapes. Assessing social values of the cultural services provided by these SFP may be more related to the assessment of the landscape values [204] rather than their role as forests per se $[203,205,206]$. The preference for a given type of landscape increases with the number of SFP and their size [202], although our perception of the landscape and its beauty varies depending on our background and knowledge [198-200, 207]. Analyses of social preferences for changes in forest area and forest structure of SFP in Picardy (northern France) and Flanders (northern Belgium) (Varela et al. submitted) found that social preferences varied depending on the intensity of disturbance of the agricultural landscape where citizens lived. It was hypothesized that this variation may be linked to the character of the population in these areas, as people living in landscapes with intensive agriculture had a more urban character, while people living in areas with less intense disturbance were more rural. These two regions showed a proportion of forest close to $6 \%$ in the agricultural landscapes and the surveyed respondents were willing to increase the area covered by SFP. The preferences of people with a more urban-like profile were determined by forest structure and also by biodiversity aspects; in contrast, the population in rural areas was mostly concerned about features related to the forest structure.

The recreational and aesthetic experience people derive from SFP may differ greatly from that in large forests, where the focus is placed on the stand features: recreationists mainly enjoy the forest-interior; in contrast, SFP embedded in agricultural matrices may be also valued as part of the agricultural landscape where they are situated, being likely to be considered as relicts of wilderness or naturalness [202]. This landscape-based appreciation depends on their size and shape. In landscapes of north France and north Belgium economic valuation surveys have shown that patches are enjoyed from both outside and inside the landscape (Varela et al. submitted). Hence, these in-out recreational components did make a difference in the way forest features are valued. People enjoying the forest-interior were more concerned than the average population to enhance biodiversity (e.g. paying for measures that will increase the number of bird or butterfly species), while people enjoying the patches from outside were more willing than the average population to increase the area of these patches (Varela et al. submitted). Forest interior and forested landscapes have also long been a source of inspiration for 
painters (e.g. "Birch forest" from Gustav Klimt, 1903 or "Dans la forêt" from Paul Cezanne, 1898-1899). Their works probably contributed to the positive perception of forest structure and forest patches by the society.

SFP may also contribute to the construction of community identity $[208 \bullet \bullet]$, since a community forest can be an element for local legends [209] signifying sanctuaries, social events. When dealing with private forests, some locations may be of personal significance for the forest owners and their families [210]. It has been observed that a share of the farmers owning land in the analysed landscapes of north France and north Belgium was reluctant to enhance the structural properties of these SFP to promote higher biodiversity levels. This may be related to their forest use, linked to hunting or wood extraction that may be to some extent hindered by (lack of) management measures aimed at increasing such structural diversity.

\section{Conclusion and Perspectives}

SFP influence their surroundings through ecological processes, mediated by patch characteristics such as their species composition, age, size and shape. Some of these processes are the basis for ES that benefit (or harm, in the case of disservices) different human activities. Mitchell et al. [28••] recently proposed a general and comprehensive framework for analysing the consequences of forest fragmentation on several ES (carbon storage, crop production, decomposition, pest regulation, soil fertility and water quality regulation). According to their work, forest fragmentation reduces the provision of most of the ES, mostly due to the negative consequences of fragmentation on biodiversity, but this could be counterbalanced by the fact that fragmentation, at a certain level, can increase the flow of ES to more beneficiaries (e.g. food foraging, hunting, and walking) through an easier accessibility. Hence, SFP produce fewer services than larger forests, but more people can potentially benefit from them. The spatial patterns of fragmentation (patch isolation, size and edge:interior ratio) are among the key drivers of the supply of many of the local and proximal ES, but there is still a strong need for more research to link given patterns to levels of services.

Moreover, new ES may emerge from fragmentation or existing ES may increase in intensity. For example, many local-proximal ES are strongly associated to the so-called "edge effect". Since a primary effect of forest fragmentation is the increased edge:interior ratio, one can expect that those local-proximal ES will increase as well. The spatial arrangement of forest patches in agricultural landscapes also matters: for a same total area and number, forest patches evenly distributed throughout the landscape are more effective in delivering local-proximal ESs, such as, e.g. pest biocontrol, than clumped patches [136]. For some ES, such as soil protection and water regulation, the localisation of forest patches within the landscape is likely of utmost importance. For instance, steep slopes are more exposed to soil erosion and water run-off than flat areas; a forest patch will thus be more efficient with respect to soil protection on the former. Similarly, it is obvious that forest patches located along streams are more efficient at regulating water flow and quality than distant patches.

Agriculture intensification threatens biodiversity in many rural areas and can jeopardize the delivery of multiple ES [211]. How to meet the rising demand for agricultural land and crop production without compromising biodiversity and associated ES is thus a critical challenge for the twenty-first century in lowland agricultural landscapes. Only recently attention has been paid to ES and many unresolved issues still remain, especially in the context of fragmented ecosystems such as SFP embedded in agricultural landscapes. ES delivered by SFP have the potential to mitigate the disservices provided by agriculture, including loss of biodiversity, agrochemical contamination of the environment, soil erosion, emission of greenhouse gas and other pollutants [212]. However, there is still an urgent need to document individual and combined (synergistic and antagonistic) ES flows and their impacts on agriculture and agricultural landscapes and to analyse whether so-called intrinsic and functional biodiversity values of these SFP can go hand in hand. Other research challenges include the determination of the spatial and temporal scales at which ES significantly contribute to agricultural productivity and thus, at which spatial and temporal scales management should be implemented to increase their efficiency; and how to design incentives to promote the provision of ES in agricultural landscapes and, ultimately to green agriculture and increase their biodiversity and scenic beauty.

Acknowledgments This research was funded by the ERA-Net BiodivERsA project smallFOREST, with the national funders ANR (France), MINECO (Spain), FORMAS (Sweden), ETAG (Estonia), DFG/DLR (Germany) and BELSPO (Belgium) part of the 2011 BiodivERsA call for research proposals.

\section{Compliance with Ethical Standards}

Conflict of Interest Guillaume Decocq, Emilie Andrieu, Jörg Brunet, Olivier Chabrerie, Pallieter De Smedt, Marc Deconchat, Brice Giffard, Elena Gorriz Mifsud, Karin Hansen, Martin Hermy, Jonathan Lenoir, Jaan Liira, Filip Moldan, Irina Prokofieva, Lars Rosenqvist, Elsa Varela, Alicia Valdés and Kris Verheyen declare that they have no conflicts of interests.

Pieter De Frenne, Martin Diekmann, Steffen Ehrmann, Annette Kolb, and Monika Wulf report grants from research foundation-flanders during study. 
Human and Animal Rights and Informed Consent This article does not contain any studies with human or animal subjects performed by the author.

\section{References}

Papers of particular interest, published recently, have been highlighted as:

- Of importance

•. Of major importance

1. Foley JA, DeFries R, Asner GP, Barford C, Bonan G, Carpenter SR, et al. Global consequences of land use. Science. 2005;309: 570-4.

2. Honnay O, Jacquemyn H, Bossuyt B, Hermy M. Forest fragmentation effects on patch occupancy and population viability of herbaceous plant species. New Phytol. 2005;166:723-36.

3. Saunders DA, Hobbs RJ, Margules CR. Biological consequences of ecosystem fragmentation: a review. Conserv Biol. 1991;5:18 32.

4. Fahrig L. Effects of habitat fragmentation on biodiversity. Annu Rev Ecol Evol Syst. 2003;34:487-515.

5. Dobson A, Lodge D, Alder J, Cumming GS, Keymer J, McGlade $\mathrm{J}$, et al. Habitat loss, trophic collapse, and the decline of ecosystem services. Ecology. 2006;87:1915-24.

6. Harper KA, Macdonald SE, Burton PJ, Chen J, Brosofske KD, Saunders SC, et al. Edge influence on forest structure and composition in fragmented landscapes. Conserv Biol. 2005;19:768-82.

7. Fischer J, Lindenmayer DB. Landscape modification and habitat fragmentation: a synthesis. Glob Ecol Biogeogr. 2007;16:265-80.

8. Verheyen K, Vellend M, Van Calster H, Peterken G, Hermy M. Metapopulation dynamics in changing landscapes: a new spatially realistic model for forest plants. Ecology. 2004;85:3302-12.

9. Jamoneau A, Chabrerie O, Closset-Kopp D, Decocq G. Fragmentation alters beta-diversity patterns of habitat specialists within forest metacommunities. Ecography. 2012;35:124-33.

10. Esseen P-A, Ehnström B, Ericson L, Sjöberg K. Boreal forests. Ecol Bull. 1997;46:16-47.

11. Honnay O, Hermy M, Coppin P. Effects of area, age and diversity of forest patches in Belgium on plant species richness, and implications for conservation and reforestation. Biol Conserv. 1999;87: 73-84.

12. Eriksson S, Skånes H, Hammer M, Lönn M. Current distribution of older and deciduous forests as legacies from historical use patterns in a Swedish boreal landscape (1725-2007). For Ecol Manag. 2010;260:1095-103.

13. Parviainen J, Bücking W, Vandekerkhove K, Schuck A, Päivinen R. Strict forest reserves in Europe: efforts to enhance biodiversity and research on forests left for free development in Europe (EUCOST-Action E4). Forestry. 2000;73:107-18.

14. Gibb H, Ball JP, Johansson T, Atlegrim O, Hjältén J, Danell K. Effects of management on coarse woody debris volume and composition in boreal forests in northern Sweden. Scand J For Res. 2005;20:213-22.

15. Lõhmus K, Liira J. Old rural parks support higher biodiversity than forest remnants. Basic Appl Ecol. 2013;14:165-73.

16. Levers C, Verkerk PJ, Müller D, Verburg PH, Butsic V, Leitão PJ, et al. Drivers of forest harvesting intensity patterns in Europe. Forest Ecol Manag. 2014;315:160-72.
17. Gabrielle B, Bamière L, Caldes N, De Cara S, Decocq G, Ferchaud F, et al. Paving the way for sustainable bioenergy in Europe: technological options and research avenues for largescale biomass feedstock supply. Renew Sust Energ Rev. 2014;33:11-25.

18. Hansen MC, Potapov PV, Moore R, Hancher M, Turubanova SA, Tyukavina A, et al. High-resolution global maps of 21st-century forest cover change. Science. 2013;342:850-3. High-resolution satellite data were used to map global and regional forest loss and gain in the world from 2000 to 2012.

19.• Gamfeldt L, Snäll T, Bagchi R, Jonsson M, Gustafsson L, Kjellander P, et al. Higher levels of multiple ecosystem services are found in forests with more tree species. Nat Commun. 2013;4: 1340. One of the first study evidencing positive relationships between tree species diversity in production forests and proxies for other biodiversity and multiple ecosystem services.

20. Shapiro J, Báldi A. Accurate accounting: how to balance ecosystem services and disservices. Ecosyst Serv. 2014;7:201-2.

21. Hooper DU, Chapin FS, Ewel JJ, Hector A, Inchausti P, Lavorel S, et al. Effects of biodiversity on ecosystem functioning: a consensus of current knowledge. Ecol Monogr. 2005;75:3-35.

22. Balvanera P, Pfisterer AB, Buchmann N, He JS, Nakashizuka T, Raffaelli D, et al. Quantifying the evidence for biodiversity effects on ecosystem functioning and services. Ecol Lett. 2006;9:114656.

23. Hector A, Bagchi R. Biodiversity and ecosystem multifunctionality. Nature. 2007;448:188-91.

24. Gamfeldt L, Hillebrand H, Jonsson PR. Multiple functions increase the importance of biodiversity for overall ecosystem functioning. Ecology. 2008;89:1223-31. This study highlights nonlinear relationships between species richness and ecosystem services.

25. Lefcheck JS, Byrnes JEK, Isbell F, Gamfeldt L, Griffin JN, Eisenhauer N, et al. Biodiversity enhances ecosystem multifunctionality across trophic levels and habitats. Nat Commun. 2014;6:6936.

26. Grime JP. Benefits of plant diversity to ecosystems: immediate, filter and founder effects. J Ecol. 1998;86:902-10.

27. Haddad NM, Brudvig LA, Clobert J, Davies KF, Gonzalez A, Holt RD, et al. Habitat fragmentation and its lasting impact on Earth's ecosystems. Sci Adv Mater. 2015;1:e1500052.

28.• Mitchell MGE, Suarez-Castro AF, Martinez-Harms M, Maron M, McAlpine C, Gaston KJ, et al. Reframing landscape fragmentation's effects on ecosystem services. Trends Ecol Evol. 2015;30: $190-8$. This paper provides a clear framework for the effects of fragmentation on ecosystem services.

29. Millennium Ecosystem Assessment. Ecosystems and human wellbeing: biodiversity synthesis. Washington: World Resources Institute; 2005.

30. Costanza R. Ecosystem services: multiple classification systems are needed. Biol Conserv. 2008;141:350-2.

31. Biber P, Borges JG, Moshammer R, Barreiro S, Botequim B, Brodrechtová Y, et al. How sensitive are ecosystem services in European forest landscapes to silvicultural treatment? Forests. 2015;6:1666-95.

32. Schmithüsen F, Hirsch F. Private forest ownership in Europe. Geneva Timber Forest Study. 2010;26:1-110.

33. Klein AM, Boreux V, Bauhus J, Chappell MJ, Fischer J, Philpott SM. Forest islands in an agricultural sea. In: Kettle CJ, Koh LP, editors. Global forest fragmentation. Delémont: CABI; 2014. p. 79-95. An assessment of two strategies, land sharing vs land sparing, in preserving biodiversity and ecosystem services in agricultural landscapes. A book entirely dedicated to forest fragmentation.

34.• Mitchell MGE, Bennett EM, Gonzalez A. Forest fragments modulate the provision of multiple ecosystem services. J Appl Ecol. 
2014;51:909-18. One of the first papers measuring and modelling the role of small forest patches on the simultaneous provision of multiple ecosystem services in agricultural landscapes.

35. FAO. State of the world's forests 2009. Rome: FAO; 2009. http:// www.fao.org/docrep/011/i0350e/i0350e00.htm).

36. Doré T, Makowski D, Malézieux E, Munier-Jolain N, Tchamitchian M, Tittonell P. Facing up to the paradigm of ecological intensification in agronomy: revisiting methods, concepts and knowledge. Eur J Agron. 2011;34:197-210.

37. Gustafsson L, Hylander K, Jacobson C. Uncommon bryophytes in Swedish forests - key habitats and production forests compared. For Ecol Manag. 2004;194:11-22.

38. Van Calster H, Vandenberghe R, Ruysen M, Verheyen K, Hermy $\mathrm{M}$, Decocq G. Unexpectedly high 20th century floristic losses in a rural landscape in northern France. J Ecol. 2008;96:927-36.

39. Paal J, Turb M, Köster T, Rajandu E, Liira J. Forest land-use history affects the species composition and soil properties of oldaged hillock forests in Estonia. J For Res. 2011;16:244-52.

40. Palo A, Ivask M, Liira J. Biodiversity composition reflects the history of ancient semi-natural woodland and forest habitatscompilation of an indicator complex for restoration practice. Ecol Indic. 2013;34:336-44.

41. Barbaro L, Giffard B, Charbonnier Y, Van Halder I, Brockerhoff EG. Bird functional diversity enhances insectivory at forest edges: a transcontinental experiment. Divers Distrib. 2014;20:149-59.

42. Paillet Y, Bergès L, Hjältén J, Ódor P, Avon C, BernhardtRömermann $\mathrm{M}$, et al. Biodiversity differences between managed and unmanaged forests: meta-analysis of species richness in Europe. Conserv Biol. 2010;24:101-12.

43. Lõhmus K, Paal T, Liira J. Long-term colonization ecology of forest-dwelling species in a fragmented rural landscape - dispersal versus establishment. Ecol Evol. 2014;4:3113-26.

44. Davies KF, Margules CR, Lawrence JF. Which traits of species predict population declines in experimental forest fragments? Ecology. 2000;81:1450-61.

45. Hendrickx F, Maelfait JP, Desender K, Aviron S, Bailey D, Diekotter $\mathrm{T}$, et al. Pervasive effects of dispersal limitation on within- and among-community species richness in agricultural landscapes. Glob Ecol Biogeogr. 2009;18:607-16.

46. Liira J, Paal T. Do forest-dwelling plant species disperse along landscape corridors? Plant Ecol. 2013;214:455-70.

47. Guerrero I, Morales M, Oñate B, Geiger JJ, Berendse F, de Snoo $\mathrm{G}$, et al. Response of ground-nesting farmland birds to agricultural intensification across Europe: landscape and field level management factors. Biol Conserv. 2012;152:74-80.

48. Kalda O, Kalda R, Liira J. Multi-scale ecology of insectivorous bats in agricultural landscapes. Agr Ecosyst Environ. 2015;199: 105-13. For animal ecology, a proper gradient from single tree to forest for a service providing group is used to show that patch is more important than line, even for high-mobility groups.

49. Kolb A, Diekmann M. Effects of environment, habitat configuration and forest continuity on the distribution of forest plant species. J Veg Sci. 2004;15:199-208.

50. Dumortier M, Butaye J, Jacquemyn H, van Camp N, Lust N, Hermy M. Predicting vascular plant species richness of fragmented forests in agricultural landscapes in central Belgium. For Ecol Manag. 2002;158:85-102.

51. Liira J, Sepp T, Kohv K. The ecology of tree regeneration in mature and old forests: combined knowledge for sustainable forest management. J For Res. 2011;16:184-93.

52. De Sanctis M, Alfo M, Attorre F, Francesconi F, Bruno F. Effects of habitat configuration and quality on species richness and distribution in fragmented forest patches near Rome. J Veg Sci. 2010;21:55-65.

53. Graae BJ. The effect of landscape fragmentation and forest continuity on forest floor species in two regions of Denmark. J Veg Sci. 2000;11:881-92.

54. Snäll T, Jonsson BG. Edge effects on wood- inhabiting fungi used as indicator species. Ecol Bull. 2001;49:255-62.

55. Siitonen P, Lehtinen A, Siitonen M. Effects of forest edges on the distribution, abundance, and regional persistence of wood-rotting fungi. Conserv Biol. 2005;19:250-60.

56. Liira J, Sepp T, Parrest O. The forest structure and ecosystem quality in conditions of anthropogenic disturbance along productivity gradient. For Ecol Manag. 2007;250:34-46.

57. Liira J, Lõhmus K, Tuisk E. Old manor parks as potential habitats for forest flora in agricultural landscapes of Estonia. Biol Conserv. 2012;146:144-54.

58. Väisänen R, Biström O, Heliövaara K. Sub-cortical Coleoptera in dead pines and spruces: is primeval species composition maintained in managed forests? Biodivers Conserv. 1993;2:95-113.

59. Desender K, Ervynck A, Tack G. Beetle diversity and historical ecology of woodlands in Flanders. Belg J Zool. 1999;129:139-55.

60. Obrist MK, Rathey E, Bontadina F, Martinoli A, Conedera M, Christe P, et al. Response of bat species to sylvo-pastoral abandonment. For Ecol Manag. 2011;61:789-98.

61. Kalda R, Kalda O, Lõhmus K, Liira J. Multi-scale ecology of woodland bat the role of species pool, landscape complexity and stand structure. Biodivers Conserv. 2014;24:337-53.

62. Lange $M$, Türke $M$, Pašalić E, Boch $S$, Hessenmöller D, Müller J, et al. Effects of forest management on ground-dwelling beetles (Coleoptera; Carabidae, Staphylinidae) in Central Europe are mainly mediated by changes in forest structure. For Ecol Manag. 2014;329:166-76.

63. Lawesson JE, de Blust G, Grashof C, Firbank L, Honnay O, Hermy M, et al. Species diversity and area-relationships in Danish beech forests. For Ecol Manag. 1998;106:235-45.

64. Grilli G, Urcelay C, Galetto L, Davison J, Vasar M, Saks Ü, et al. The composition of arbuscular mycorrhizal fungal communities in the roots of a ruderal forb is not related to the forest fragmentation process. Environ Microbiol. 2015;17:2709-20.

65. Wulf M, Kolk J. Plant species richness of very small forests related to patch configuration, quality, heterogeneity and history. J Veg Sci. $1985 ; 25: 1267-77$.

66. Dupré C, Ehrlén J. Habitat configuration, species traits and plant distributions. J Ecol. 2002;90:796-805.

67. Vellend M, Verheyen K, Jacquemyn H, Kolb A, Van Calster H, Peterken G, et al. Extinction debt of forest plants persists for more than a century following habitat fragmentation. Ecology. 2006;87: 542-8. The paper highlights that for forest plant species with relatively low rates of population extinction and colonization ("slow" species) an extinction debt persists more than a century after forest fragmentation.

68. UNECE, FAO. State of Europe's Forests 2011. Status and trends in sustainable forest management in Europe. 2011.

69. UNECE. Forest Resources of Europe, CIS, North America, Australia, Japan and New Zealand. Geneva: United Nations; 2000.

70. Sourdril A, Andrieu E, Cabanettes A, Elyakime B, Ladet S. How to maintain domesticity of usages in small rural forests? Lessons from forest management continuity through a French case study. Ecol Soc. 2012;17:art6.

71. Gustaffson L, Baker SC, Bauhus J, Beese WJ, Brodie A, Kouki J, et al. Retention forestry to maintain multifunctional forests: a world perspective. Bioscience. 2012;62:633-45.

72. Brang P, Spathelf P, Larsen JB, Bauhus J, Boncìna A, Chauvin C, et al. Suitability of close-to-nature silviculture for adapting temperate European forests to climate change. Forestry. 2014;87:492- 
503. Review of hands-on guidelines on how to change forest management practices to adapt to climate change.

73. Verkerk PJ, Anttila P, Eggers J, Lindner M, Asikainen A. The realisable potential of woody biomass from forests in the European Union. For Ecol Manag. 2011;261:2007-15.

74. Burkhard B, Kroll F, Müller F, Windhorst W. Landscapes' capacities to provide ecosystem services - a concept for land-cover based assessments. Landsc Online. 2009;15:1-22.

75. Fahrig L, Baudry J, Brotons L, Burel FG, Crist TO, Fuller RJ, et al. Functional landscape heterogeneity and animal biodiversity in agricultural landscapes. Ecol Lett. 2011;14:101-12.

76. Stryamets N, Elbakidze M, Ceuterick M, Angelstam P, Axelsson R. From economic survival to recreation: contemporary uses of wild food and medicine in rural Sweden, Ukraine and NW Russia. J Ethnobiol Ethnomed. 2015;11:53.

77. Schulp CJE, Thuiller W, Verburg PH. Wild food in Europe: a synthesis of knowledge and data of terrestrial wild food as an ecosystem service. Ecol Econ. 2014;105:292-305.

78. Łuczaj Ł, Pieroni A, Tardío J, Pardo-de-Santayana M, Sõukand R, Svanberg I, et al. Wild food plant use in 21 st century Europe: the disappearance of old traditions and the search for new cuisines involving wild edibles. Acta Soc Bot Pol. 2012;81:359-70.

79. Rosenblatt DL, Heske EL, Nelson SL, Barber DM, Miller MA, MacAllister B. Forest fragments in east-central Illinois: islands or habitat patches for mammals? Am Midl Nat. 1999;141:115-23.

80. Santos T, Telleria JL, Virgos E. Dispersal of Spanish juniper Juniperus thurifera by birds and mammals in a fragmented landscape. Ecography. 1999;22:193-204.

81. Nilsson SG. Forests in the temperate-boreal transition: natural and man-made features. Ecol Bull. 1987;46:61-71.

82. Pimentel D, Lach L, Zuniga R, Morrison D. Environmental and economic costs of non-indigenous species in the United States. BioScience. 2000;50:53-65.

83. Szabo E, Pomazi I. Environmental indicators of Hungary 2002. Budapest: Ministry of Environment and Water; 2003.

84. With CA. The landscape ecology of invasive spread. Conserv Biol. 2002;16:1192-203

85. Bartuszevige AM, Gorchov DL, Raab L. The relative importance of landscape and community features in the invasion of an exotic shrub in a fragmented landscape. Ecography. 2006;29:213-22.

86. Guirado M, Pino J, Rodà F. Understorey plant species richness and composition in metropolitan forest archipelagos: effects of forest size, adjacent land use and distance to the edge. Glob Ecol Biogeogr. 2006;15:50-62.

87. Gorchov DL, Henry MC, Frank PA. Invasion of an exotic shrub into forested stands in an agricultural matrix. Invas Plant Sci Manag. 2014;7:336-44.

88. Martin PH, Canham CD, Marks PL. Why forests appear resistant to exotic plant invasions: intentional introductions, stand dynamics, and the role of shade tolerance. Front Ecol Env. 2009;7:142-9.

89. Brothers T, Spingarn A. Forest fragmentation and alien plant invasion of Central Indiana old-growth forests. Conserv Biol. 2003;6:91-100

90. Gorchov DL, Trisel DE. Competitive effects of the invasive shrub, Lonicera maackii (Rupr.) Herder (Caprifoliaceae), on the growth and survival of native tree seedlings. Plant Ecol. 2003;166:13-24.

91. Montero-Castaño A, Vilà M. Impact of landscape alteration and invasions on pollinators: a meta-analysis. J Ecol. 2012;100:884 93.

92. Devlaeminck AR, De Schrijver A, Hermy M. Variation in throughfall deposition across a deciduous beech (Fagus sylvatica L.) forest edge in Flanders. Sci Total Environ. 2005;337:241-52.

93. Lindner M, Fitzgerald JB, Zimmermann NE, Reyer C, Delzon S, van der Maaten E, et al. Climate change and European forests: what do we know, what are the uncertainties, and what are the implications for forest management? J Environ Manag. 2010;146: 69-83.

94. Schelhaas MJ, Nabuurs G, Schuck A. Natural disturbances in the European forests in the 19th and 20th centuries. Glob Change Biol. 2003;9:1620-33.

95. Pawson SM, Brin A, Brockerhoff EG, Lamb D, Payn TW, Paquette A, et al. Plantation forests, climate change and biodiversity. Biodivers Conserv. 2013;22:1203-27.

96.• Valdés A, Lenoir J, Gallet-Moron E, Andrieu E, Brunet J, Chabrerie $\mathrm{O}$, et al. The contribution of patch-scale conditions is greater than that of macroclimate in explaining local plant diversity in fragmented forests across Europe. Glob Ecol Biogeogr. $2015 ; 24: 1094-105$. This study demonstrates that patch quality conditions are more important than global gradients in driving local plant species diversity.

97. Liira J, Jürjendal I, Paal J. Do forest plants conform to the theory of island biogeography: the case study of bog islands. Biodivers Conserv. 2014;23:1019-39.

98. Hobbs RJ, Higgs E, Harris JA. Novel ecosystems: implications for conservation and restoration. Trends Ecol Evol. 2009;24:599-605. The concept of novel ecosystems is building up to be the future of conservation biology and ecosystem services.

99. Perhans K, Appelgren L, Jonsson F, Nordin U, Soderstrom B, Gustafsson L. Retention patches as potential refugia for bryophytes and lichens in managed forest landscapes. Biol Conserv. 2009;142:1125-233.

100. Keppel G, Van Niel KP, Wardell-Johnson GW, Yates CJ, Byrne M, Mucina L, et al. Refugia: identifying and understanding safe havens for biodiversity under climate change. Glob Ecol Biogeogr. 2012;21:393-404.

101. Heroldová M, Bryja J, Zejda J, Tkadlec E. Structure and diversity of small mammal communities in agriculture landscape. Agric Ecosyst Environ. 2007;120:206-10.

102. Bertrand R, Lenoir J, Piedallu C, Riofrío-Dillon G, de Ruffray P, Vidal C, et al. Changes in plant community composition lag behind climate warming in lowland forests. Nature. 2011;479:51720.

103. De Frenne P, Rodríguez-Sánchez F, Coomes DA, Baeten L, Verstraeten G, Vellend M, et al. Microclimate moderates plant responses to macroclimate warming. Proc Natl Acad Sci U S A. 2013;110:18561-5.

104. De Frenne P, Rodríguez-Sánchez F, De Schrijver A, Coomes DA, Hermy M, Vangansbeke P, et al. Light accelerates plant responses to warming. Nature Plants. 2015; art15110.

105. Lenoir J, Svenning JC. Latitudinal and elevational range shifts under contemporary climate change. In: Encyclopedia of Biodiversity, 2nd Edition. Academic Press; 2013. pp. 599-611.

106. Keppel G, Mokany K, Wardell-Johnson GW, Phillips BL, Welbergen JA, Reside AE. The capacity of refugia for conservation planning under climate change. Front Ecol Environ. 2015;13: 106-12.

107. Wilby A, Thomas MB. Natural enemy diversity and pest control: patterns of pest emergence with agricultural intensification. Ecol Lett. 2002;5:353-60.

108. Hawkins BA, Mills NJ, Jervis MA, Price PW. Is the biological control of insects a natural phenomenon? Oikos. 1999;86:493506.

109. Losey JE, Vaughan M. The economic value of ecological services provided by insects. Bioscience. 2006;56:311-23.

110. Tenhumberg B, Poehling HM. Syrphids as natural enemies of cereal aphids in Germany: aspects of their biology and efficacy in different years and regions. Agric Ecosyst Environ. 1995;52: 39-43.

111. Magura T. Carabids and forest edge: spatial pattern and edge effect. For Ecol Manag. 2002;157:23-37. 
112. Schmidt MH, Tscharntke I. The role of perennial habitats for Central European farmland spiders. Agric Ecosyst Environ. 2005; 105:235-42.

113. Schweiger O, Maelfait JP, Wingerden W, Hendrickx F, Billeter R, Speelmans M, et al. Quantifying the impact of environmental factors on arthropod communities in agricultural landscapes across organizational levels and spatial scales. J Appl Ecol. 2005;42: 1129-39.

114. Billeter R, Liira J, Bailey D, Bugter R, Arens P, Augenstein I, et al. Indicators for biodiversity in agricultural landscapes: a panEuropean study. J Appl Ecol. 2008;45:141-50.

115. Naylor RL, Ehrlich P. Natural pest control services and agriculture. In: Daily GC, editor. Nature's services: societal dependence on natural ecosystems. Washington: Island Press; 1997. p. 151-74.

116. Weibull AC, Östman Ö, Granqvist Å. Species richness in agroecosystems: the effect of landscape, habitat and farm management. Biodivers Conserv. 2003;12:1335-55.

117. Bianchi FJJA, Goedhart PW, Baveco JM. Enhanced pest control in cabbage crops near forest in The Netherlands. Landsc Ecol. 2008;23:595-602.

118. Power AG. Ecosystem services and agriculture: tradeoffs and synergies. Philos Trans R Soc B. 2010;365:2959-71.

119. McCracken GF, Westbrook JK, Brown VA, Eldridge M, Federico $\mathrm{P}$, Kunz TH. Bats track and exploit changes in insect pest populations. PLoS One. 2012;7:e43839.

120. Diamond JM. The island dilemma: lessons of modern biogeographic studies for the design of natural preserves. Biol Conserv. 1975;7:129-46.

121. Simberloff D, Abele LG. Refuge design and island biogeographic theory: effects of fragmentation. Am Nat. 1982;120:41-50.

122. Thomson LJ, Hoffmann AA. Spatial scale of benefits from adjacent woody vegetation on natural enemies within vineyards. Biol Control. 2013;64:57-65.

123. Shackelford G, Steward PR, Benton TG, Kunin WE, Potts SG, Biesmeijer JC, et al. Comparison of pollinators and natural enemies: a meta-analysis of landscape and local effects on abundance and richness in crops. Biol Rev. 2013;88:1002-21.

124. Samu F, Szinetár C. On the nature of agrobiont spiders. J Arachnol. 2002;30:389-402.

125. Bianchi FJJA, Booij CJH, Tscharntke T. Sustainable pest regulation in agricultural landscapes: a review on landscape composition, biodiversity and natural pest control. Proc R Soc B. 2006;273:1715-27.

126. Klein AM, Vaissière BE, Cane JH, Steffan-Dewenter I, Cunningham SA, Kremen C, et al. Importance of pollinators in changing landscapes for world crops. Proc R Soc B. 2007;274: 303-13.

127. Ollerton J, Winfree R, Tarrant S. How many flowering plants are pollinated by animals? Oikos. 2011;120:321-6.

128. Rathcke BJ, Jules ES. Habitat fragmentation and plant-pollinator interactions. Curr Sci. 1993;65:273-7.

129. Kwak MM, Velterop O, van Andel J. Pollen and gene flow in fragmented habitats. Appl Veg Sci. 1998;1:37-54.

130. Ghazoul J. Pollen and seed dispersal among dispersed plants. Biol Rev. 2005;80:413-43.

131. Hadley AS, Betts MG. The effects of landscape fragmentation on pollination dynamics: absence of evidence not evidence of absence. Biol Rev. 2012;87:526-44.

132. Aguilar R, Galetto L. Effects of forest fragmentation on male and female reproductive success in Cestrum parqui (Solanaceae). Oecologia. 2004;138:513-20.

133. Aguilar R, Ashworth L, Galetto L, Aizen MA. Plant reproductive susceptibility to habitat fragmentation: review and synthesis through a meta-analysis. Ecol Lett. 2006;9:968-80.
134. Kolb A. Reduced reproductive success and offspring survival in fragmented populations of the forest herb Phyteuma spicatum. J Ecol. 2005;93:1226-37.

135. Kolb A. Habitat fragmentation reduces plant fitness by disturbing pollination and modifying response to herbivory. Biol Conserv. 2008;141:2540-9.

136. Tscharntke T, Klein AM, Kruess A, Steffan-Dewenter I, Thies C. Landscape perspectives on agricultural intensification and biodiversity — ecosystem service management. Ecol Lett. 2005;8:85774.

137. Ricketts TH, Regetz J, Steffan-Dewenter I, Cunningham SA, Kremen C, Bogdanski A, et al. Landscape effects on crop pollination services: are there general patterns? Ecol Lett. 2008;11: 499-515.

138. Garibaldi LA, Steffan-Dewenter I, Kremen C, Morales JM, Bommarco R, Cunningham SA, et al. Stability of pollination services decreases with isolation from natural areas despite honey bee visits. Ecol Lett. 2011;14:1062-72.

139. Dunn RR. Global mapping of ecosystem disservices: the unspoken reality that nature sometimes kills us. Biotropica. 2010;42: 555-7.

140. Gern L, Estrada-Peña A, Frandsen F, Gray JS, Jaenson TGT, Jongejan F, et al. European reservoir hosts of Borrelia burgdorferi sensu lato. Zentralblatt Für Bakteriologie. 1998;287(3):196-204.

141. Rauter C, Hartung T. Prevalence of Borrelia burgdorferi sensu lato genospecies in Ixodes ricinus ticks in Europe: a meta-analysis. Appl Environ Microbiol. 2005;71:7203-16.

142. Reye AL, Hübschen JM, Sausy A, Muller CP. Prevalence and seasonality of tick-borne pathogens in questing Ixodes ricinus ticks from Luxembourg. Appl Environ Microbiol. 2010;76: 2923-31.

143. Allan BF, Keesing F, Ostfeld RS. Effect of forest fragmentation on Lyme disease risk. Conserv Biol. 2003;17:267-72.

144. Kiffner C, Zucchini W, Schomaker P, Vor T, Hagedorn P, Niedrig $\mathrm{M}$, et al. Determinants of tick-borne encephalitis in counties of southern Germany, 2001-2008. Int J Health Geogr. 2010;9:42.

145. Halos L, Bord S, Cotté V, Gasqui P, Abrial D, Barnouin J, et al Ecological factors characterizing the prevalence of bacterial tickborne pathogens in Ixodes ricinus ticks in pastures and woodlands. Appl Environ Microbiol. 2010;76:4413-20.

146. Schmidt KA, Ostfeld RS. Biodiversity and the dilution effect in disease ecology. Ecology. 2001;82:609-19.

147. Ostfeld RS. Biodiversity loss and the rise of zoonotic pathogens. Clin Microbiol Infec. 2009;15:40-3.

148. De la Torre A, Bosch J, Iglesias I, Muñoz MJ, Mur L, MartínezLópez B, et al. Assessing the risk of African swine fever introduction into the European Union by wild boar. Transbound Emerg Dis. 2015;62:272-9.

149. Costard S, Wieland B, de Glanville W, Jori F, Rowlands R, Vosloo $\mathrm{W}$, et al. African swine fever: how can global spread be prevented? Philos Trans R Soc B. 2009;364:2683-96.

150. Virgós E. Factors affecting wild boar (Sus scrofa) occurrence in highly fragmented Mediterranean landscapes. Can J Zool. 2002;80:430-5.

151. Hewlett JD. Principles of forest hydrology. Athens: University of Georgia Press; 1982.

152. Maes WH, Heuvelmans G, Muys B. Assessment of land use impact on water-related ecosystem services capturing the integrated terrestrial - aquatic system. Environ Sci Technol. 2009;43:7324 30.

153. Sikka AK, Samra JS, Sharda VN, Samraj P, Lakshmanan V. Low flow and high flow responses to converting natural grassland into bluegum (Eucalyptus globulus) in Nilgiris watersheds of South India. J Hydrol. 2003;270:12-26.

154. Smakhtin VU. Low flow hydrology: a review. J Hydrol. 2001;240:147-86. 
155. Brauman KA, Daily GC, Duarte TK, Mooney HA. The nature and value of ecosystem services: an overview highlighting hydrologic services. Annu Rev Environ Resour. 2007;32:67-98.

156. Molden D. Water for food, water for life: comprehensive assessment of water management in agriculture. London: Earthscan, in association with Colombo; International Water Management Institute (IWMI); 2007.

157. Edwards PJ, Schoonover JE, Williard KJW. Guiding principles for management of forested, agricultural, and urban watersheds. J Contemp Water Res Educ. 2015;154:60-84.

158. Boardman J, Poesen J. Soil erosion in Europe: major processes, causes and consequences. In: Boardman J, Poesen J, editors. Soil erosion in Europe. Chichester: Wiley; 2006. p. 479-87.

159. Morgan RPC. Soil erosion and conservation. London: Wiley; 2005.

160. Cerdan O, Govers G, Le B, Van Oost YK, Poesen J, Saby N, et al. Rates and spatial variations of soil erosion in Europe: a study based on erosion plot data. Geomorphology. 2010;122:167-77.

161. de Figueiredo T, Fonseca F, Martins A. Soil loss and run-off in young forest stands as affected by site preparation technique: a study in NE Portugal. Eur J For Res. 2012;131:1747-60.

162. Janssens IA, Freibauer A, Ciais P, Smith P, Nabuurs GJ, Folberth $\mathrm{G}$, et al. Europe's terrestrial biosphere absorbs 7 to $12 \%$ of European anthropogenic $\mathrm{CO}_{2}$ emissions. Science. 2003;300: 1538-42.

163. Kasischke ES. Boreal ecosystems in the global carbon cycle. In: Kasischke ES, Stocks BJ, editors. Fire, climate change, and carbon cycling in the boreal forests. New York: Springer; 2000. p. 19-31.

164. Goodale CL, Apps MJ, Birdsey RA, Field CB, Heath LS, Houghton RA, et al. Forest carbon sinks in the Northern Hemisphere. Ecol Appl. 2002;12:891-9.

165. Liski J, Perruchoud D, Karjalainen T. Increasing carbon stocks in the forest soils of Western Europe. For Ecol Manag. 2002;169: $163-79$.

166. Karjalainen T, Pussinen A, Liski J, Nabuurs GJ, Eggers T, Lapveteläinen $T$, et al. Scenario analysis of the impacts of forest management and climate change on the European forest sector carbon budget. For Policy Econ. 2003;5:141-55.

167. Nabuurs GJ, Schelhaas MJ, Mohren GMJ, Field CB. Temporal evolution of the European forest sector carbon sink from 1950 to 1999. Glob Change Biol. 2003;9:152-60.

168. Kauppi PE, Mielikäinen K, Kuusela K. Biomass and carbon budget of European forests, 1971 to 1990. Science. 1992;256:70-4.

169. Boisvenue C, Running SW. Impacts of climate change on natural forest productivity - evidence since the middle of the 20th century. Glob Change Biol. 2006;12:862-82.

170. Ciais P, Sabine C, Bala G, Bopp L, Brovkin V, Canadell J, et al. Carbon and other biogeochemical cycles. In: Stocker TF, Qin D, Plattner G-K, Tignor M, Allen SK, Boschung J, Nauels A, Xia Y, Bex V, Midgley PM, editors. Climate change 2013: the physical science basis. Contribution of working group I to the fifth assessment report of the intergovernmental panel on climate change. Climate change 2013: the physical science. Cambridge: Cambridge University Press; 2013.

171. Kukumägi M, Ostonen I, Kupper P, Truu M, Tulva I, Varik M, et al. The effects of elevated atmospheric humidity on soil respiration components in a young silver birch forest. Agric For Meteorol. 2014;194:167-74.

172. Stendahl J, Johansson MB, Eriksson E, Nilsson Å, Langvall O. Soil organic carbon in Swedish spruce and pine forests - differences in stock levels and regional patterns. Silva Fennica. 2010;44:5-21.

173. Vesterdal L, Clarke N, Sigurdsson BD, Gundersen P. Do tree species influence soil carbon stocks in temperate and boreal forests? For Ecol Manag. 2013;309:4-18.
174. Ziter $\mathrm{C}$. The effect of forest fragmentation on aboveground carbon stocks and tree diversity: a case study of the Montérégie, Quebec. $\mathrm{PhD}$ thesis. Montreal; Department of Biology, McGill University: 2013. pp. 121.

175. Crockatt M, Bebber D. Edge effects on moisture reduce wood decomposition rate in a temperate forest. Glob Change Biol. 2015;21:698-707.

176. Young A, Mitchell N. Microclimate and vegetation edge effects in a fragmented podocarp-broadleaf forest in New Zealand. Biol Conserv. 1994;67:63-72.

177. Delgado JD, Arroyo NL, Arévalo JR, Fernández-Palacios JM. Edge effects of roads on temperature, light, canopy cover, and canopy height in laurel and pine forests (Tenerife, Canary Islands). Landsc Urban Plan. 2007;81:328-40.

178. Heithecker TD, Halpern CB. Edge-related gradients in microclimate in forest aggregates following structural retention harvests in western Washington. For Ecol Manag. 2007;248:163-73.

179. Weathers KC, Cadenasso ML, Pickett STA. Forest edges as nutrient and pollutant concentrators: potential synergisms between fragmentation, forest canopies, and the atmosphere. Conserv Biol. 2002;15:1506-14.

180. Beier C, Gundersen P. Atmospheric deposition to the edge of a spruce forest in Denmark. Environ Pollut. 1989;60:257-71.

181. Spangenberg A, Kölling C. Nitrogen deposition and nitrate leaching at forest edges exposed to high ammonia emissions in southern Bavaria. Water Air Soil Pollut. 2004;152:233-55.

182. Wuyts K, Verheyen K, De Schrijver A, Cornelis WM, Gabriels D. The impact of forest edge structure on longitudinal patterns of deposition, wind speed, and turbulence. Atmos Environ. 2008;42:8651-60.

183. Wuyts K, De Schrijver A, Staelens J, Gielis M, Geudens G, Verheyen K. Patterns of throughfall deposition along a transect in forest edges of silver birch and Corsican pine. Can J For Res. 2008;38:449-61.

184. Devlaeminck R, Bossuyt B, Hermy M. Seed dispersal from a forest into adjacent cropland. Agric Ecosyst Environ. 2005;107: 57-64.

185. Rastetter EB, Ryan MG, Shaver GR, Melillo JM, Nadelhoffer KJ, Hobbie JE, et al. A general biogeochemical model describing the responses of the $\mathrm{C}$ and $\mathrm{N}$ cycles in terrestrial ecosystems to changes in $\mathrm{CO}(2)$, climate, and $\mathrm{N}$ deposition. Tree Physiol. 1991;91: $101-26$.

186. Mäkipää R, Lehtonen A, Peltoniemi M. Monitoring carbon stock changes in European forests using forest inventory data. In: Dolman AJ, Freibauer A, Valentini R, editors. The continentalscale greenhouse gas balance of Europe. Ecological Studies 203. New York: Sringer-Verlag; 2008. p. 191-210.

187. Vejre H, Callesen I, Vesterdal L, Raulund-Rasmussen K. Carbon and nitrogen in Danish forest soils - contents and distribution determined by soil order. Soil Sci Soc Am J. 2003;67:335-43.

188. Dijkstra JMP, Reinds GJ, Kros H, Berg B, de Vries W. Modelling soil carbon sequestration of intensively monitored forest plots in Europe by three different approaches. For Ecol Manag. 2009;258: 1780-93.

189. Berg B, Matzner E. Effect of N deposition on decomposition of plant litter and soil organic matter in forest systems. Environ Rev. 1997;5:1-25.

190. Franklin O, Högberg P, Ekblad A, Ågren GI. Pine forest floor carbon and accumulation in response to $\mathrm{N}$ and $\mathrm{PK}$ additions: bomb ${ }^{14} \mathrm{C}$ modeling and respiration studies. Ecosystems. 2003;6: 644-58.

191. Ramirez KS, Craine JM, Fierer N. Consistent effects of nitrogen amendments on soil microbial communities and processes across biomes. Glob Change Biol. 2012;18:1918-27. 
192. Troy A, Wilson MA. Mapping ecosystem services: practical challenges and opportunities in linking GIS and value transfer. Ecol Econ. 2006;60:435-49.

193. Termansen M, Zandersen M, McClean CJ. Spatial substitution patterns in forest recreation. Reg Sci Urban Econ. 2008;38:81-97.

194. Hörnsten L, Fredman P. On the distance to recreational forests in Sweden. Landsc Urb Plan. 2000;51:1-10.

195. Abildtrup J, Garcia S, Olsen SO, Stenger A. Spatial heterogeneity in forest recreation. Ecol Econ. 2013;92:67-77.

196. Eswaran H, van den Berg E, Reich P. Organic carbon in soils of the world. Soil Sci Soc Am J. 1993;57:192-4.

197. Christie M, Hanley N, Hynes S. Valuing enhancements to forest recreation using choice experiment and contingent behaviour methods. J For Econ. 2007;13:75-102.

198. Scarpa R, Hutchinson W, Chilton S, Buongiorno J. Importance of forest attributes in the willingness to pay for recreation: a contingent valuation study of Irish forests. For Policy Econ. 2000;1:31529.

199. Nielsen AB, Olsen SB, Lundhede T. An economic valuation of the recreational benefits associated with nature-based forest management practices. Landsc Urban Plan. 2007;80:63-71.

200. Gundersen VS, Frivold L. Public preferences for forest structures: a review of quantitative surveys from Finland, Norway and Sweden. Urban For Urban Green. 2008;7:241-58.

201. Franco D, Franco D, Mannino I, Zanetto G. The impact of agroforestry networks on scenic beauty estimation: the role of a landscape ecological network on a socio-cultural process. Landsc Urban Plan. 2003;62:119-38.

202. Dramstad WE, Tveit MS, Fjellstad WJ, Fry GLA. Relationships between visual landscape preferences and map-based indicators of landscape structure. Landsc Urban Plan. 2006;78:465-74.

203. Tagliafierro C, Longo A, Van Eetvelde V, Antrop M, Hutchinson WG. Landscape economic valuation by integrating landscape ecology into landscape economics. Environ Sci Policy. 2013;32: 26-36.

204. Smith MD, Sanchirico JN, Wilen JE. The economics of spatialdynamic processes: application to renewable resources. J Environ Econ Manag. 2009;57:104-21.

205. Campbell D. Willingness to pay for rural landscape improvements: combining mixed logit and random-effects models. J Agric Econ. 2007;58:467-83.

206. Brey R, Riera P, Mogas J. Estimation of forest values using choice modeling: an application to Spanish forests. Ecol Econ. 2007;64: 305-12.

207. Campbell D, Vedel SE, Thorsen BJ, Jacobsen JB. Heterogeneity in the WTP for recreational access: distributional aspects. J Environ Plan Manag. 2014;57:1200-19.

208.• De Groot RS, Alkemade R, Braat L, Hein L, Willemen L. Challenges in integrating the concept of ecosystem services and values in landscape planning, management and decision making. Ecol Complex. 2010;7:260-72. This paper provides an overview of the challenges involved in applying ecosystem service assessment and valuation to environmental management, discusses some solutions and provides a comprehensive and practical framework.

209. Daniel TC, Muhar A, Arnberger A, Aznar O, Boyd JW, Chan KM, et al. Contributions of cultural services to the ecosystem services agenda. Proc Natl Acad Sci. 2012;109:8812-9.

210. Domínguez G, Shannon M. A wish, a fear and a complaint: understanding the (dis)engagement of forest owners in forest management. Eur J For Res. 2011;130:435-50.

211. Matson PA, Parton WJ, Power AG, Swift MJ. Agricultural intensification and ecosystem properties. Science. 1997;277:504-9.

212. Dale VH, Polasky S. Measures of the effects of agricultural practices on ecosystem services. Ecol Econ. 2007;64:286-96. 